rain falling at a rate greater than $0.5 \mathrm{~mm} / \mathrm{min}$, contrary to the generally accepted belief that the predominant charge was negative; the laboratory experiments showed that drops of distilled water, broken into spray by a jet of air, became positively charged, the air becoming negatively charged. From these results and the fact that, in thunderstorms, there are vertical currents greater than $8 \mathrm{~m} / \mathrm{s}$, that is, enough to carry the largest raindrops upwards until they split, Simpson concluded that a thundercloud must have positive electricity in its central part near its base and negative electricity higher up and away from the centre. This he maintained with firm confidence, in a succession of papers, against the protagonists of the 'influence theory'. Eventually he designed apparatus, earried by free balloons, which recorded the sign of the electric field during the ascent through thunderclouds. Ascents from Kew in 1934-6, and again in 1937-9, showed a positive charge in the upper layers, for which C. T. R. Wilson had contended, a wide distribution of negative in the lower layers with a positive charge near the active centre, as Simpson had pictured it. The upper positive charge and the negative charge beneath it were always at levels where temperature was well below the ice-point. Simpson interpreted this as meaning that the separation of the electricity there was due to collisions of ice crystals.

In 1909 Captain Scott invited Simpson to go as meteorologist with him to the Antarctic. Simpson accepted, came to England to collect the equipment and sailed from London on the Terra Nova in June 1910, arriving at McMurdo Sound on January 4, 1911. The ship had nearly foundered when the pumps failed in a very bad storm in December. Observations on the voyage of potential gradient, round the clock, gave for the first time its diurnal variation at sea. At Cape Evans he kept complete meteorological and magnetic records for a year until he was recalled, a year earlier than expected, owing to the illness of Dr. G. T. Walker, his chief in India. In the following seven years, first full of administrative work, then service with the army in Mesopotamia and secondment to the Indian Munitions Board, he wrote a paper demonstrating that coronae seen in the Antarctic could only have been due to liquid-water drops in the atmosphere at temperatures far below the ice-point; and a second paper showing that the spatial distribution of the amplitude and phase of the semi-diurnal variation of atmospheric pressure indicated that it was compounded of two waves, one from east to west and one from equator to pole. In 1920 Simpson was the physicist member of the Egyptian Government Commission appointed to advise on projects for the further regulation of the Nile.

At the end of that work Simpson returned to England to succeed Sir Napier Shaw as director of the Meteorological Office, a post which he held from September 6, 1920, to September 2, 1938. Control of the Office had been transferred to the Air Ministry; and the Meteorological Branches of the Admiralty and Air Ministry, and the British Rainfall Organization, had been officially included in the Office. It fell to Simpson to make the unified organization a good and satisfied scientifie service. This ho did surprisingly well, in spite of the 'Geddes Axe' and the fact that, like Aphrodite, the Meteorological Office sprang from the sea. The staff was largely drawn from those who had entered meteorology during the War; one of the ablest was most unfortunately lost with the airship $R$ 101. By 1926 the Office was running well enough for Simpson to be able to take up again the thunderstorm problem and, after that, the balance between the retained solar radiation and the outward radiation from earth and atmosphere. By taking account of Hettner's confirmation of the 'window' in the infra-red spectrum of water-vapour, indicated in 1898 in the experiments of Rubens and Aschkinass, he was able to make close approximations to the outgoing radiation from the Earth, the troposphere and the stratosphere in different zones of latitude and thence the horizontal transfer of heat necessary to ensure radiative equilibrium. This led him to the deduction that an increase in solar radiation would cause an increase in cloud and precipitation and possibly have a bearing on the problem of ice ages. He pursued this idea in a number of papers, arriving at the conclusion that an increase of solar radiation would cause first an extension of the polar ice and then a retreat, while the subsequent decrease of the radiation would turn the retreat into an extension followed by a second retreat.

On the outbreak of War in 1939, Simpson offered his services to his successor, Sir Nelson Johnson, who accepted his offer and put him in charge of the four Observatories and the Edinburgh Office, with his headquarters at Kew, where he was able to make further investigations of the electricity carried down by rain. He was president of the Royal Meteorological Society during 1941-42. His increasing deafness in the 1930's made him decline nomination as successor to E. van Everdingen, on the latter's retirement in 1935 from the presidency of the International Meteorological Committee in whose work he had taken and continued to take a very active part.

Simpson was elected Fellow of the Royal Society in 1915 and appointed K.C.B. in 1935. He married Dorothy, daughter of Cecil and Alice Stephen, at Sydney in Septem. ber 1914. They had three sons and a daughter, all still living. He died on Now Year's Day in hospital at Bristol after a short illness. The simple funeral service on January 6 , with the first few moving verses of Wisdom $I I I$, was held at Westbury-on-Trym, whero they had lived since they left London in 1961.

E. GouD

\section{Prof. A. F. Barker}

Prof. A. F. Barker died on July 22, 1964, in Portland, Victoria, Australia, at the age of ninety-six. Several obituary notices have already been published, in which tributes were paid to this remarkable man who had devoted the whole of his long life to the textile industry. He was head of the Textile Department at the Bradford Technical College from 1892 until 1914 and professor of textile industries in the University of Leods from 1914 until his retirement in 1933 . At the invitation of the Chinese Government he then took up an appointment as professor of textile industries at the University of ChaioTung, Shanghai, but because of the Japanese invasion of China he eventually migrated to Australia, living first in Melbourne and then in Portland, Victoria, where his address was appropriately 'Merino Cottage'.

Prof. Barker was a great enthusiast for textiles. $\mathrm{He}$ was very aware of the need for the industry to adopt scientific methods, and to that end he was proud to have introduced into the Department of Textile Industries in Loeds such men as the late Prof. W. T. Astbury and Prof. J. B. Speakman. He realized also the importance of a professional organization for the textile industry and was a Founder Member of the Textile Institute, which now has a membership approaching 8,000 . In addition, he was active in promoting more local societies such as the Bradford Textile Society.

His death affords an opportunity to place on record the vast changes which occurred in the wool textile industry during his working life. In his early days textiles was essentially a craft industry, dominated by highly skilled men whose jealously guarded methods of processing had little to do with rational thought. Nevertheless, the products were of surprisingly good quality and British wool textiles were highly regarded throughout the world. Man-made fibres were unknown and the processing machinery had changed little over the years. Although the achievements of science were well appreciated in some industrios, the potentialities of science in the wool textile industry were almost completely unrecognized. Within Prof. Barker's life-time, however, this situation changed completely. He was not himself a professional 
scientist, but he recognized that the future even of the wool industry would be determined by the extent to which it used the findings of the inereasing number of chemists, physicists, engineers and biologists being trained in the universities. Fortunately the wool industry has taken full advantage of the opportunity and is now based. on sophisticated applied science and engineering.

Whoreas fifty years ago tho structure of wool was almost unknown, now, as a result largely of the work pioneered by Astbury and Speakman in Leeds and actively pursued by other groups of investigators not only in Britain but also in France, Sweden, Germany, the United States, Australia and South Africa, it is sufficiently well established to form the basis on which new and commercially significant processes have been developed and which increase the usefulness of wool. In the engineering field, processing has been rationalized and new machines such as the Raper 'Auto-leveller', the Ambler 'Superdraft' system of spinning, and the Sulzer weaving machine have been produced, while advances in biological research and animal husbandry have greatly increased the amount of wool available. The industry is progressive, modern and exciting. In Britain it is well served by an active Research Association and there are ample facilitios for training personnel in technical colleges and in universities. The modern industry is based on sound science and ingenious invention and its problems are challonging ones. It offers, and will continue to offer, intellectually rewarding careers for young people with a wide variety of talents, for fow industries require the services not only of seientists, technologists, engineers and economists but also of men and women with a true flair for style and design.

In a wider context a note such as this would not be complete without some mention of the fundamental scientific consequences of the researches on the structure of wool, for out of these have emerged important aspects of the new science of molecular biology. Moreover, the complexity of wool - an insoluble protein - necessitated the development of new techniques to obtain information about the sequence and proportions of the constituent amino-acids. One of these procedures, that of partition chromatography, was developed by A. J. P. Martin and R. L. M. Synge working in the laboratories of the Wool Industries Research Association, and for this work they were awarded the 1952 Nobel Prize in Chemistry.

Until just before his death Prof. Barker retained an active interest in textile education and developments, and he must have been gratified to observe the ever-increasing significance of science in the industry which meant so much to him.

C. S. WHEWELL

\section{Dr. Peter Pringsheim}

AFrer a long life-time devoted to the subject of luminescence, Dr. Peter Pringsheim died on November $20,1963$.

He was born on March 19, 1881, son of Prof. Alfred Pringsheim, mathematician, of Munich, and took his doctorate there under Röntgen in 1906 with a dissertation on "The Minimum Potential for Spark Dischargo". Periods of work at Göttingen, Cambridge (under J. J. Thomson) and Berlin followed, and the summer of 1914 found him in Australia with the meoting of tho British Association for the Advancement of Science. Here he was interned for the period of the First World War, after which he returned to Berlin, married his Belgian wife in 1923, and was appointed full professor of the university in 1930. Three years later the Hitler régime caused him to leave Germany for a chair in the University of Brussels, which he retained until 1949. However, he was caught up with again in 1940 by the invasion of Belgium in the Second World War, and sent to internment in the south of France, but obtained liberation the following year on an American visa to carry out research at the University of California, Berkeley. His knowledge of the lumi- nescence of uranyl compounds was doubtless the reason for his transfer to the Univorsity of Chicago, during 1942-44, and again as visiting professor during 1946-47, after an interval as director of research, Ray Control Co., Pasadena.

During 1947-55 he occupied the post of senior scientist, Argonne National Laboratory, Chicago, retiring at the age of seventy-five to Antwerp.

Pringsheim was an active research worker and an assiduous amasser of information from all sources on his chosen subject. Eighty publications, in fourteen journals, describe his investigations; the subjocts include the polarization of fluorescence from vapours and dye solutions; general observations on fluorescence and photochemical changes in solutions of hydrocarbons, of dyes and of uranyl compounds and metal complexes; and luminescence and colour centres in irradiated crystals. The introductory chapter in his book Luminescence (1943) exhibits his interest in the ancient history of the subject together with his precise yet light touch in description.

His first book, Fluorescenz und Phosphoreszenz im Lichte der neueren Atom-theorie (Springer, Berlin, 1921; third edition, 1928), was written during his time of internment in Australia, and remained for many years the only authoritative book on the subject. Important contributions were made also in. Volumes 19, 21 and 23 of the Handbuch der Physik (Springer, Berlin). In 1943 he produced, in collaboration with Marcel Vogel, Luminescence of Liquids and Solids (Interscience), and finally, in 1949, his massivo work, Fluorescence and Phosphorescence (Interscience), dedicated to James Franck. This book, containing more than 1,900 references to the literature, has been of immense value to recent workers in this subject of increasing topical interest, not only because of its completeness and reliability, but also because of the clear and critical exposition of the facts in a manner so characteristic of the author.

Pringsheim, during his life-time, was aequainted or associated with all the leading figures carrying out work on luminescence, such as James Franck, Pohl, Hertz, Jablonski, Terenin and Vavilov, and followed its transformation from vague pre-quantum ideas to present-day concepts, constantly both forward and backward looking. Without him the subject would have lacked a great teachor and adviser.

In 1937 he was elected Foreign Momber of the Polish Academy. His wife survives him.

E. J. Bowen

\section{Dr. A. A. Benedetti-Pichler}

Dr. Anton Alexander Benedetti-Pichler, who died suddenly on December 10, 1964, was a pioneer in the establishment of microchemistry in the United Statos.

Born in Vienna, Austria, in 1894, Dr. Pichler received degrees at the Technische Hochschule in Graz, where he worked for many years with the pioneer in microchemistry, Hofrat Friedrich Fmich. It was during his years with Dr. Emich that Pichler learned from him the importance of extreme attention to minute details, which showed up through all his life in his contributions to the field of microchemistry and to general analytical techniques. "During the early years," he once said, "Emich was a very exacting chief, and I did not have an easy time. Later, he relaxed when he found that $\mathrm{I}$ really tried to do my best."

After obtaining tho venia legend $i$ in analytical chemistry, Dr. Pichler decided to take up permanent rosidence in the United States in 1929, in order to introduce the inorganic microchemical working procedures of Dr. Emich and his co-workers there, and to raiso the standards of the analytical chemist.

Mainly through the consistent efforts of Dr. Pichler in the 1930's there have beon laid tho solid foundations of the Microchemistry Section in the American Chemical 